\title{
Projects Based Learning To Increase Entrepreneurial Interest For Student Entrepreneurship Program
}

\author{
Agus Aan Jiwa Permana ${ }^{*}$ \\ ${ }^{1}$ Department of Engineering and Vocational, Universitas Pendidikan Ganesha, Jalan Udayana 11, Singaraja, Bali, Indonesia
}

A R T I C L E I N F O

Article history:

Received 20

February 2018

Received in revised

form

6 March 2018

Accepted 15 April

2018

Available online 25

May 2018

Keywords:

Project Proposal,

Entrepreneurial Student,

Student

Entrepreneurship

Program

\section{A B S T R A C T}

In an effort to encourage the nation's economic development through the potential of vocational education in an effort to reduce unemployment and create employment in Indonesia. The government provides opportunities for students to entrepreneurship. With experience about entrepreneurship expected by students after graduating from university students can independently develop business in various sectors. This study aims to help students who have difficulty in pouring their creative ideas into a proposal. This is certainly received serious attention through the process of intense guidance from lecturers especially for students who have never written a paper. In maximizing the potential that exists in a limited time, the development of ideas into proposals can be done by utilizing the time on project management lectures and information systems management with project-based learning methods. The result is that students can learn to write project proposals and produce products that help students in joining entrepreneurship programs.Keywords:one or more word(s) or phrase(s), that it's important, spesific, or representative for the article.

\section{Introduction}

Education aims to form creative, knowledgeable human resources, have the skills and skills, and can open employment opportunities to absorb labor. Through vocational education, the graduates generated are more geared to possess the necessary skills of the industrial world. But in addition to work, graduates should also be directed to entrepreneurship. Student program for entrepreneurship, get support from government through Student Creativity Program in Entrepreneurship field (PKM-K) which started from 1998 until today. Then in 2009 the government provides capital to students through the Student Entrepreneurial Program (PMW) which aims to run the science of entrepreneurship owned by students (Kemenristekdikti, 2017, p.19).

The government of President Joko Widodo strongly supports the young generation of the nation to be creative doing something useful in encouraging the economic progress of the nation by providing opportunities for students to entrepreneurship, create new jobs so as to reduce unemployment in Indonesia. However, it is not easy to explore the potential and business ideas that will be run by the students. Students often dizzy when asked to make a paper proposal due to the lack of knowledge of students in putting ideas into writing. Proposal is a prerequisite to propose ideas related to the business that will be developed so that if passed will be given funds by the government. Students are confused in writing proposals for lack of ideas, whereas many business ideas can be tried in the field as a novice entrepreneur.

This study aims to explore the ability of students in thinking raises the idea, then write down the idea in a proposal. Of course a big project, the idea does not just appear but need a process long enough through several stages in the field such as observation, searching for information from the internet and 
conducting interviews with people who can provide information related to the project to be done. With so many processes that must be passed to build a business, it needs a solution to produce a proposal in a short time in accordance with the format.

Research shows that the entrepreneurial knowledge factor that will increase the higher entrepreneurship interest (Ermawati and Widodo, 2015, pp.876-887). So that students need to be equipped with complex knowledge related to business that will dijaalnkan. Informatics Management Study Program is a vocational program located at the Faculty of Engineering and Vocational, Universitas Pendidikan Ganesha (Undiksha) in North Bali. In following the PMW, it needs to be done a fairly mature preparation and a long time. In guiding Informatics Management students to follow PMW takes extra time. Based on the experience of the writer as a student counselor, in determining the idea until realized into a proposal PMW takes approximately four months, so it needs to prepare well.

Lecture schedules and solid student activities become one of the obstacles that will affect the process in completing the proposal. Then another problem is the ability and interest in writing is still low on the students. Lecturers in charge of guiding students, also have additional duties both on campus and outside the campus, so the guidance process PMW proposal not maximal.

With constraints on students who have never attended scientific papers, the authors provide a solution by applying project-based learning methods to Project Management courses (Manpro) that are collaborated with other subjects to accelerate the proposal-making process. During the socialization related to PMW in the faculty, the proposed PMW proposal is suggested to produce the product and can do the marketing of the product online. Apparently in entrepreneurship is not just to make products, but also must be able to market online. The solution to this problem is to create a website-based marketing medium.

Simultaneously, in the even semester of 2017 the authors also manage the Information Systems Management (MSI) course. So in after making a proposal, in marketing the product will be done with the website. The process of website development must go through several stages and takes quite a long time. So the authors apply project-based learning to the course of MSI to produce a website. Because by applying Project Based Learning (PBL), is highly potential to provide valuable experience in enhancing creative thinking skills and can work in a team or group to shape creativity and learning experiences through real projects (Nur Jannatu Na'imah and Wardani, 2015, pp. 1566-1574).

PBL focuses on the concepts of a discipline involving students actively solving problems and tasks as well as providing opportunities to work autonomously in producing products (Muspiroh, 2015, pp.1-8). So that learners are able to do exploration, assessment, sistesis, and information to produce various forms of learning outcomes (Wulandari, 2016, pp. 247-254).

Application of PBL in learning is to provide projects to students so that students provide business ideas through the process of observation and field interviews, planning, reporting and budgeting, realize, and distribute the resulting product. By applying the PBL in MSI and Manpro lecture students are expected to be able to produce a business plan that can be realized in the field, thus providing an opportunity for students to enter the business world.

This method is quite effective and challenging as a learning tool so that learners are encouraged to be more independent (Nur Jannatu Na'imah and Wardani, 2015, pp. 1566-1574). With PBL provides an opportunity for teachers to manage classroom learning by involving project work (Mulyadi, 2015, pp. 385395).

Having got the experience of entrepreneurship, will provide experience in the field of business to students. Experience gained in the business, if ditekuni will open new business opportunities to absorb labor. By opening a business opportunity is expected to affect the Indonesian economy and reduce unemployment.

The same thing delivered (Lestari and Harnanik, 2012, pp.1-6) that being an entrepreneur is one way to create jobs independently.

\section{Method}

This research uses quantitative descriptive method by processing value based on field observation. This research is conducted for six months (one semester) by using the population is a student semester even academic year 2016/2017. The sampling technique is a saturated sample method involving as many as 25 people. The saturated sample is a sampling technique in which all populations are sampled (Margareta, 2013, pp.1-24). 
This is done because the number of students majoring in Management Informatics, Ganesha University of Education in academic year 2016/2017 only 25 people.

Students obtain MSI and Manpro courses in the same semester and are taught by the same lecturers, so as to facilitate the process of control during college. The method used in the lectures is Project Based Learning by implementing the strategy Contextual Teaching and Learning (CTL).

The reason for implementing such a strategy is that CTL has the characteristics of linking course content to real-world situations to train students' logical and objective thinking skills in solving problems, as well as providing a learning experience that can provide the challenge of adding knowledge. Knowledge and skill factors are used to produce effective learning (Sunaga et al., 2016, pp. 1-9).

The first stage of the PBL method is that students form a group and each group issues their business ideas. In project management, cooperation between competent teams with the ability to communicate and soft skill is required (Motschnig-pitrik and Figl, 2007, pp. 15-21).

After discussing the business idea that has been determined, the next task is to create a business concept, among others, describes the business situation analysis and business profile. Once the student can provide a clear picture related to the business idea, it continues at the stage of business location analysis, marketing strategy, production process, consumer target, and marketing area. All stages must be done through direct observation to the field through the process of direct interviews with certain parties and then written in the form of a report so as to further clarify the description of business ideas that will be implemented.

The next task is to make the organization's design related to the business to be run. The design contains a chairman, a member with a description of each task. After this stage, students are given steps to draw up a budget plan. In preparing the budget there are some things to be considered such as the percentage of the cost incurred should be appropriate. Then the funds designed must be appropriate and effective to finance the business to be run. The PBL method is to study the environment, build practical experience and learning in real terms and ensure and support to realize the process effectively (Santos and Alexandre, 2015, pp. 1-8).

The next stage is to develop a website-based online marketing media by involving social media. This is one of the important assessments used to pass a proposal. The development of online marketing media is done by giving the project to the students through the lecture of Information Systems Management (MSI). System development process is done through several stages such as problem identification, data collection, needs analysis, system design, and implementation or website development.

Table 1. Comparison of Project Management Indicator Values

\begin{tabular}{llll}
\hline No & Aspects of Project Manpro Assessment & Pre-Test (\%) & Post-Test (\%) \\
\hline 1 & Idea Determination, & 52.8 & 78.4 \\
2 & Description of Business, & 46.4 & 75.2 \\
3 & Level of Realization, & 44.8 & 82.4 \\
4 & Target Consumer, & 33.6 & 76.8 \\
5 & Management Structure, & 27.2 & 71.2 \\
$6 \quad$ Budget Planning & 23.2 & 69.6 \\
& & & \\
Minimum value & $\mathbf{2 0}$ & $\mathbf{6 6}$ \\
Max value & $\mathbf{6 2}$ & $\mathbf{9 8}$ \\
Average value (\%) & $\mathbf{4 7 . 5 5}$ & $\mathbf{8 6 . 9 1}$ \\
Difference (\%) & $\mathbf{3 9 . 3 6}$ & \\
\hline
\end{tabular}

After completing all the stages, the proposal can be brought and corrected to the supervisor for the improvement of the proposal in accordance with the format and provisions in accordance with applicable guidelines. In a short time, students must make revisions in accordance with the supervisor input and then the proposal will be directly collected in hardcopy format to the committee and upload the softcopy proposal online on the prepared link.

The evaluation process in this study used the comparison of Pre-test and Post-test results to determine the effect of PBL and CTL methods on learning outcomes processed statistically using T-Test. 


\section{Discussion}

In this study, there are several indicators for assessing in two different courses. In the course of project management there are six indicators used in the assessment of Business Idea, Business Description, Level of Realization, Consumer Target, Management Structure, and Budget Planning. Based on the results of the comparison of pre-test and post-test there are differences in the value shown on Table 1.

Based on the results in Table 1, it can be explained that in determining the business idea has increased by $26 \%$. Then in describing the business to be run increased by $29 \%$. In terms of realizing the project an increase of $38 \%$, determining the right consumer has increased by $43 \%$, forming the management structure increased by $44 \%$, and the most difficult thing to do is plan the budget and in the end can be better by having percentage of $46 \%$ and is a very high rise from the Pre-test results.

Table 2. Comparison of Value of Information System Management Indicators

\begin{tabular}{clcc}
\hline No & Aspects of Project MSI Assessment & Pre-Test(\%) & Post-Test(\%) \\
\hline 1 & Layout & 45.6 & 76.8 \\
2 & Menu Navigation & 44 & 72.8 \\
3 & Templates & 45.6 & 72.8 \\
4 & Content & 33.6 & 79.2 \\
5 & Promotion product & 27.2 & 75.2 \\
6 & Booking Process & 21.6 & 74.4 \\
7 & Contact & 22.4 & 73.6 \\
& & & \\
Minimum value & $\mathbf{2 0}$ & $\mathbf{6 0}$ & \\
Max value & $\mathbf{5 4}$ & $\mathbf{9 8}$ & \\
Average value (\%) & $\mathbf{3 8 . 0 0}$ & $\mathbf{8 6 . 1 8}$ & \\
Difference (\%) & $\mathbf{4 8 . 1 8}$ & & \\
\hline
\end{tabular}

The smallest student score at the Pre-test is 20 and after Post-test becomes 66 so that from the learning process conducted by cumulative has succeeded to give positive impact to the student with the difference of the average value of $39.36 \%$ from the average value of $47.55 \%$ to $86.91 \%$.

Furthermore in the course of Information Systems Management there are several indicators used to assess the website made by students that is about Layout, Navigation Menu, Templates, Content, Promotion, Product, Process Booking, Contact. Creation of Content Management System (CMS) -based website so that web can be developed accordingly in a short time. The following results of Pre-test and Post-test of this project can be seen as in Table 2.

Based on the process undertaken during the learning, has produced products in the form of PMW proposal and marketing website. By applying the PBL method with Contextual Teaching and Learning (CTL) strategy, it has successfully led the students in developing a website that is suitable to be used for product promotion. In the process of creating a website that initially minimal content, through the revision process increased from the value of $33.6 \%$ to $79.2 \%$. In the field of product promotion also increased by $33.6 \%$ to $79.2 \%$. Previously many websites did not explain how to order products, and after the Post-test progressively improved, this was proven by an increasing value of $52.8 \%$ which is the highest percentage of all indicators. Then on the website has provided contact not only mobile phone number but in the form of e-mail, whatsUp, Line, Instagram, and other social media that can help the communication process in marketing which increased by $51.2 \%$. 
Table 3. Proposal PMW 2017 Department of Information Management

\begin{tabular}{|c|c|c|c|}
\hline No & Draft Proposal PMW & Description & Status \\
\hline & "Spoon Of Light (SOL)" & Creative effort to develop decorative & Escaped in-static \\
\hline 1 & $\begin{array}{l}\text { Usaha Lampu Hias Dari } \\
\text { Sendok Bekas }\end{array}$ & $\begin{array}{l}\text { lamps made from bottles and spoon } \\
\text { used }\end{array}$ & \\
\hline 2 & $\begin{array}{l}\text { Metamorfosis Kardus Bekas } \\
\text { Menjadi Frame Foto Dan Tas } \\
\text { Cantik }\end{array}$ & $\begin{array}{l}\text { Creative business made from used } \\
\text { cardboard into frames and bags }\end{array}$ & Escaped in-static \\
\hline 3 & $\begin{array}{l}\text { SG } \\
\text { (Sela Geprok) Bumbu Khas } \\
\text { Bali }\end{array}$ & $\begin{array}{l}\text { Culinary-based food business with } \\
\text { Balinese spices }\end{array}$ & $\begin{array}{l}\text { Escaped in-static } \\
\text { and in-dynamic }\end{array}$ \\
\hline 4 & $\begin{array}{l}\text { KEDAS } \\
\text { (Kripik Daun Singkong) Rasa } \\
\text { Pedas Manis }\end{array}$ & $\begin{array}{l}\text { Food business by utilizing cassava } \\
\text { leaves to be chips }\end{array}$ & $\begin{array}{l}\text { Do not pass the } \\
\text { selection }\end{array}$ \\
\hline 5 & $\begin{array}{l}\text { DOLI } \\
\text { (Dodol Strawberi) khas } \\
\text { bedugul }\end{array}$ & $\begin{array}{l}\text { Food business by utilizing strawberry } \\
\text { into dodol }\end{array}$ & Escaped in-static \\
\hline 6 & E-BOX (Exploding Box) & $\begin{array}{l}\text { Creative efforts create a box of paper } \\
\text { and can be open to surprise people. The } \\
\text { contents of the box can be memorable } \\
\text { photos. }\end{array}$ & Escaped in-static \\
\hline
\end{tabular}

In this research has resulted six proposals done in groups such as Table 3. In the initial selection process one proposal did not pass, this is due to lack of proper in drafting the use of budgeted funds or administrative problems even though the idea has been very promising.

In the end, through the in-dynamic selection process only one PWM proposal succeeds in obtaining the funds because it passes in-static and in-dynamic. This became a history because for the first time the PMW proposal of the department of informatics management passed and managed to get grant funds.

\begin{tabular}{lccccccr}
\hline & \multicolumn{4}{c}{ Tests of Normality } & \multicolumn{3}{c}{ Shapiro-Wilk } \\
& KELAS & Statistic & df & Sig. & Statistic & df & Sig. \\
\hline MANPRO & PRE & .201 & 22 & .051 & .883 & 22 & .014 \\
& POST & .141 & 22 & $.200^{*}$ & .900 & 22 & .030 \\
a. Lilliefors Significance Correction & & & & & & \\
*. This is a lower bound of the true significance. & & & & & \\
\hline
\end{tabular}

\section{Test of Homogeneity of Variance}

\begin{tabular}{llrrrr} 
& Levene Statistic & df1 & df2 & \multicolumn{1}{c}{ Sig. } \\
\hline MANPRO & 3.056 & 1 & 42 & .088 \\
& Based on Mean & 1.639 & 1 & 42 & .207 \\
& Based on Median & 1.639 & 1 & 35.697 & .209 \\
& $\begin{array}{l}\text { Based on Median and with } \\
\text { adjusted df }\end{array}$ & & & & \\
Based on trimmed mean & 2.967 & 1 & 42 & .092 \\
\hline
\end{tabular}


Paired Samples Test

\begin{tabular}{|c|c|c|c|c|c|c|c|c|}
\hline & \multicolumn{5}{|c|}{ Paired Differences } & \multirow[b]{3}{*}{$\mathrm{t}$} & \multirow[b]{3}{*}{$\mathrm{df}$} & \multirow{3}{*}{$\begin{array}{l}\text { Sig. (2- } \\
\text { tailed) }\end{array}$} \\
\hline & \multirow[b]{2}{*}{ Mean } & \multirow{2}{*}{$\begin{array}{c}\text { Std. } \\
\text { Deviatio } \\
\mathrm{n}\end{array}$} & \multirow{2}{*}{$\begin{array}{c}\text { Std. Error } \\
\text { Mean }\end{array}$} & \multicolumn{2}{|c|}{$\begin{array}{l}\text { 95\% Confidence } \\
\text { Interval of the } \\
\text { Difference }\end{array}$} & & & \\
\hline & & & & Lower & Upper & & & \\
\hline $\begin{array}{r}\text { Pair } 1 \text { MANPRO PRE - } \\
\text { MANPRO POST }\end{array}$ & -39.36364 & $\begin{array}{r}11.2018 \\
1\end{array}$ & 2.38823 & $\begin{array}{r}- \\
44.3302 \\
4\end{array}$ & $\begin{array}{r}- \\
34.3970 \\
3\end{array}$ & 16.482 & 21 & .000 \\
\hline
\end{tabular}

Figure 1. Project Management Data Analysis Using T-test

Based on Figure 1 on data analysis using T-test, got $t$ arithmetic equal to 16.482 with significance 0.000 . These results indicate that the significance is smaller than 0.05 , so H0 is rejected and Ha accepted. Therefore, it can be concluded that there is a significant effect of project-based methods on the success of learning Project Management learning to students.

Based on Figure 2 on data analysis using T-test, obtained t count equal to 22.844 with significance 0.000 . These results indicate that the significance is smaller than 0.05 , so HO is rejected and Ha accepted. Therefore, it can be concluded that there is a significant effect of project-based methods on the success of learning Management Information Systems to students.

\begin{tabular}{|rr|r|r|r|r|r|r|}
\hline & & \multicolumn{3}{|c|}{ Kolmogorov-Smirnov $^{\mathrm{a}}$} & \multicolumn{3}{c|}{ Shapiro-Wilk } \\
\cline { 3 - 8 } & KELAS & Statistic & \multicolumn{1}{c|}{$\mathrm{df}$} & \multicolumn{1}{c|}{ Sig. } & Statistic & \multicolumn{1}{c|}{$\mathrm{df}$} & \multicolumn{1}{c|}{ Sig. } \\
\hline MSI & PRE & .143 & 22 & $.200^{*}$ & .944 & 22 & .245 \\
& & .162 & 22 & .136 & .904 & 22 & .036 \\
\hline
\end{tabular}

a. Lilliefors Significance Correction

*. This is a lower bound of the true significance.

Test of Homogeneity of Variance

\begin{tabular}{|c|c|c|c|c|c|}
\hline & & Levene Statistic & df1 & $\mathrm{df} 2$ & Sig. \\
\hline \multirow[t]{4}{*}{ MSI } & Based on Mean & .852 & 1 & 42 & .361 \\
\hline & Based on Median & .475 & 1 & 42 & .495 \\
\hline & $\begin{array}{l}\text { Based on Median and with } \\
\text { adjusted df }\end{array}$ & .475 & 1 & 39.529 & .495 \\
\hline & Based on trimmed mean & .660 & 1 & 42 & .421 \\
\hline
\end{tabular}

Paired Samples Test

\begin{tabular}{|c|c|c|c|c|c|c|c|c|}
\hline & \multicolumn{5}{|c|}{ Paired Differences } & \multirow[b]{3}{*}{$\mathrm{t}$} & \multirow[b]{3}{*}{$\mathrm{df}$} & \multirow{3}{*}{$\begin{array}{l}\text { Sig. (2- } \\
\text { tailed) }\end{array}$} \\
\hline & \multirow[b]{2}{*}{ Mean } & \multirow[b]{2}{*}{ Std. Deviation } & \multirow{2}{*}{$\begin{array}{l}\text { Std. } \\
\text { Error } \\
\text { Mean }\end{array}$} & \multicolumn{2}{|c|}{$\begin{array}{l}95 \% \text { Confidence } \\
\text { Interval of the } \\
\text { Difference }\end{array}$} & & & \\
\hline & & & & Lower & Upper & & & \\
\hline $\begin{array}{ll}\text { Pa } & \text { MSI PRE - } \\
\text { ir } & \text { MSI POST } \\
1 & \end{array}$ & -48.18182 & 9.89293 & 2.10918 & $\begin{array}{r}- \\
52.5681 \\
0\end{array}$ & -43.79554 & | & 21 & .000 \\
\hline
\end{tabular}

Figure 2. Data Analysis Management Information System Using T-test 


\section{Conclusions and Reccomendation}

The research has proven that with the collaboration of project management and Information System Management that implement project-based learning methods, successfully encourage students' interest to write proposals and describe their business ideas. Evidently students have been able to produce six entrepreneurial proposals that telibat following the selection process at the institution level. With the ability of students who have never participated in the competition to write scientific papers.

The process of writing the proposal through several stages of the determination of ideas by observation and searching data into the field. It also proves that in some journals it says that project-based methods effectively challenge learners for individual learning. Through the T-Test test process showed that the collaboration of two courses showed significant results. The development of project-based lectures is effectively used to encourage students' interest in writing and realizing their ideas. With teamwork and field knowledge with a blend of skills to produce a product in the form of proposals and websites.

\section{References}

Ermawati and Widodo, J. (2015) 'Pengaruh Pengetahuan Wirausaha Dan Kepercayaan Diri Terhadap Minat Berwirausaha Siswa Kelas XI Jurusan Pemasaran Smk Negeri 2 Semarang Tahun Ajaran 2014/2015', Economic Education Analysis Journal, 4(3), pp. 876-887.

Kemenristekdikti (2017) Panduan Program Kewirausahaan Mahasiswa Indonesia.

Lestari, D. I. and Harnanik, S. H. (2012) 'Pengaruh Prakerin, Prestasi Belajar, Lingkungan Keluarga Terhadap Minat Berwirausaha Siswa', Economic education analysis journal, 1(2), pp. 1-6.

Margareta, S. (2013) Hubungan Pelaksanaan Sistem Kearsipan Dengan Efektivitas Pengambilan Keputusan Pimpinan Universitas Pendidikan Indonesia. Universitas Pendidikan Indonesia.

Motschnig-pitrik, R. and Figl, K. (2007) Developing Team Competence as Part of a Person Centered Learning Course on Communication and Soft Skills in Project Management.

Mulyadi, E. (2015) 'Penerapan Model Project Based Learning', Jurnal Pendidikan Teknologi dan Kejuruan, 22, pp. 385-395.

Muspiroh, N. (2015) 'Penerapan Project Base Learning ( PBP ) Bagi Mahasiswa', Scientiae Educatia, 5.

Nur Jannatu Na'imah, S. and Wardani, S. (2015) 'Penerapan Pembelajaran Berbasis Proyek Berbantuan ELearning', Jurusan Kimia FMIPA Universitas Negeri Semarang, 9(2), pp. 1566-1574.

Santos, S. and Alexandre, G. (2015) Applying PBL in Project Management Education : a Case Study of an Undergraduate Course.

Sunaga, Y., Washizaki, H., Kakehi, K., Fukazawa, Y. and Yamato, S. (2016) 'Relation between Combinations of Personal Characteristic Types and Educational Effectiveness for a Controlled Project-based Learning Course', 6750(c), pp. 1-9. doi: 10.1109/TETC.2016.2526664.

Wulandari, F. E. (2016) 'Pengaruh Pembelajaran Berbasis Proyek Untuk Melatihkan Keterampilan Proses Mahasiswa', 5(2), pp. 247-254. 